\title{
The Effect of Placement and Career Development on Employee Performance of PT. Mandiri Karya in Jakarta
}

\author{
Ade Muslimat \\ Serang Raya University \\ Email: ademuslimatmufrodi@gmail.com
}

( Received : February 20-2020 ; revised : April 20-2020 ; published : June 30-2020 )

\begin{abstract}
This study aims to determine the effect of career placement and development on employee performance at PT. Mandiri Karya in Jakarta. The method used is explanatory research with analytical techniques using statistical analysis with regression testing, correlation, determination and hypothesis testing. The results of this study the placement of a significant effect on employee performance by $41.6 \%$, the hypothesis test obtained $\mathrm{t}$ count $>\mathrm{t}$ table or $(8,133>1,986)$. Career development has a significant effect on employee performance by $43.8 \%$, the hypothesis test is obtained $\mathrm{t}$ count $>\mathrm{t}$ table or (8.508> 1.986). Career placement and development simultaneously have a significant effect on employee performance by $52.6 \%$, the hypothesis test is obtained F count> F table or $(51.106>2,700)$.
\end{abstract}

Keywords: Placement; Career development; Employee performance.

\section{INTRODUCTION}

Employee performance in general is an embodiment of work carried out by employees that are usually used as a basis or reference for evaluating employees in an organization. Good performance is a step towards achieving organizational goals, therefore, performance is also a deciding tool in achieving organizational goals so it needs to be strived to improve employee performance (Eka, 2020; Ogar \& Ude, 2020).

Every company in carrying out its activities must have a goal to be achieved, to achieve or realize these goals, each company must be clever in choosing a strategy, especially human resource planning which is essentially focused on certain steps taken by management (Asmanurhidayani et al., 2018; Daraba et al., 2018; Pratiwi et al., 2019). The availability of permanent workers to occupy positions and the right time in order to achieve the objectives and various targets set (Hermawati \& Fadillah, 2018; Jasmani, 2019; Juhaeri, 2020). They view work as something noble so human resource factors in the execution of work should not be ignored. This can be seen from the smaller demand to pay attention to the human aspect rather than just focusing on the technological and economic aspects.

Increasing competition in the world of work spurs companies to continue to improve performance, so as to achieve corporate goals that bring profit and benefit the community. To achieve company goals electively, it is of course required high quality human resources (labor) and in accordance with the current field.

Companies in increasing productivity perform a form of activity that is the placement of workers or employees who have different levels of competence. This difference in ability is determined based on the results of recruitment (recruitment) and qualifications (qualifications) 
184 | Jurnal Ilmiah Ilmu Administrasi Publik: Jurnal Pemikiran dan Penelitian Administrasi Publik Volume 1o Number 1, January - June 2020. Page 183-194

of the company. Even for the promotion of the position itself is determined based on the appointment of work itself. Job placement is one important factor that must not be ignored in achieving company goals. If the company puts the wrong employee in a place that is not their expertise, the employee's performance will not be maximal so that the company's goals are ineffective and inefficient. Employee performance and placement is very influential on the achievement of company goals.

If the placement of employees in accordance with their expertise, the employee's performance will be maximal so that the company's goals can be achieved. In addition, in increasing the workforce (employees) there are other aspects for the achievement of company goals, namely career development of employees (career development). When employees do the same thing and repeatedly, it will have a bad impact, then the employee will experience burnout. To prevent this from happening, the employee career development process is definitely needed. Which, according Hanrahmawan (2012) career development is an effort to improve the technical, theoretical, conceptual and moral abilities of employees in accordance with the needs of the job / position through education and training.

In carrying out a job, the company needs to conduct a performance appraisal so that the effectiveness and success of the employee's performance can be known. According to Bott et al., (2016) argues "Performance appraisal is the process of evaluating how well employees do their work when compared to a set of standards, and then communicating that information to employees". According to Scott \& Tiessen (1999) argues "The performance evaluation is the assessment of a person's job performance of employees, which is one of the most important responsibilities that exist in a manager".

According to Kampkötter (2017) "Performance appraisal is useful to improve performance in the future, provide value feedback about the quality of work to then study the desired improvement in performance". Scott \& Tiessen (1999) argue "Employee performance appraisal is a means to improve employees who are not doing their job properly and make employees know their position and role in creating the achievement of company goals".

Based on the explanation above, the writer takes the title of the research: Effect of career placement and development on employee performance at PT. Mandiri Karya in Jakarta. The hypothesis that the researchers propose is:

H1: Allegedly there is a significant influence between placement on employee performance at PT. Mandiri Karya in Jakarta .

$\mathrm{H}$ 2: Allegedly there is a significant influence between career development on employee performance at PT. Mandiri Karya in Jakarta .

H3: It is suspected that there is a significant influence between career placement and career development simultaneously on employee performance at PT. Mandiri Karya in Jakarta 
Ade Muslimat; The Effect of Placement and Career Development on Employee Performance ...| 185

\section{METHOD}

The type of research used is associative, where the aim is to find out the connection between. Population is a group of objects that are determined through a certain criteria that will be categorized into objects that will be examined. According to Creswell \& Creswell (2017) defining population is the number of generalized areas consisting of objects or subjects that have the quality and characteristics set by the researcher and then conclusions are drawn. The population in the study amounted to 95 respondents PT. Mandiri Karya in Jakarta. According to Creswell \& Creswell (2017) namely "The sample is the number and characteristics possessed by the population". Whereas (Creswell, 2013; Creswell \& Poth, 2018) argues that "The sample is part or representative of the population under study". The sampling technique in this study is saturated sampling, where all members of the population are sampled. Thus the sample in this study amounted to 95 respondents. In analyzing the data used instrument test, classical assumption test, regression, coefficient of determination and hypothesis testing.

\section{RESULT AND DISCUSSION}

\section{Classic assumption test}

$\mathrm{U}$ ji classical assumptions are intended to determine the accuracy of the data. According to Yildiz et al., (2017)" A regression model will be used for forecasting, a good model is a model with minimum forecasting errors ". Therefore, a model before use should fulfill a number of assumptions, commonly called classical assumptions. In this study used classical assumption test is included: Normality Test, Test Multicollinearity, Test autocorrelation, and Test Heterokedastis itas. The results are as follows:

\section{Normality Test}

Normality test is carried out to test whether in the regression model, the dependent variable and the independent variable are normally distributed or not normally distributed. Normality test results with the Kolmogorov-Smirnov Test .

Table 1

Kolmogorov-Smirnov normality results

Tests of Normality

\begin{tabular}{lr|r|r|r|r|r}
\hline & \multicolumn{3}{c}{ Kolmogorov-Smirnov a } & \multicolumn{3}{c}{ Shapiro-Wi lk } \\
& Statistics & \multicolumn{1}{c}{ df } & \multicolumn{1}{c}{ Sig. } & Statistics & \multicolumn{1}{c}{ df } & \multicolumn{1}{c}{ Sig. } \\
\hline Employee Performance (Y) & .083 & 95 & .101 & .973 & 95 & .046 \\
\hline
\end{tabular}

a. Lilliefors Significance Correction

Based on the test results in table 1 obtained significance value $\alpha=0,101$ where the value is greater than the value of $\alpha=0.050$ or $(0,101>0.05)$. Thus, the assumption of the distribution of equations in this test is normal. 
186 Jurnal Ilmiah Ilmu Administrasi Publik: Jurnal Pemikiran dan Penelitian Administrasi Publik Volume 10 Number 1, January - June 2020. Page 183-194

\section{Multiconilierity Test}

Mutilolinearity testing is done to believe that between independent variables do not have multicollinearity or do not have the effect of correlation between variables determined as models in the study. Multicollinearity test is done by looking at the value of Tolerance Value and Variance Inflation Factor (VIF). The test results are presented in table 2.

Table 2

Multicollinearity Test Results with Collinierity Statistics .

Coefficients $^{\text {a }}$

\begin{tabular}{|c|c|c|c|c|c|}
\hline \multirow[b]{2}{*}{ Model } & \multicolumn{2}{|c|}{$\begin{array}{c}\text { Unstandardized } \\
\text { Coefficients }\end{array}$} & \multirow{2}{*}{$\begin{array}{c}\text { Standardized } \\
\text { Coefficients } \\
\text { Beta }\end{array}$} & \multicolumn{2}{|c|}{$\begin{array}{l}\text { Collinearity } \\
\text { Statistics }\end{array}$} \\
\hline & B & Std. Error & & Tolerance & VIF \\
\hline $\begin{array}{ll}1 & \text { (Constant) }\end{array}$ & 9,565 & 2,946 & & & \\
\hline Placement (X1) & .352 & .085 & 380 & 613 & 1,632 \\
\hline Career Development (X2) & .419 & .090 & .425 & 613 & 1,632 \\
\hline
\end{tabular}

a. Dependent Variable: Employee Performance (Y)

Based on the test results in Table 2 the value of tolerance of each independent variable: $0.613<1.0$ and a value Variance Inflation Factor ( VIF) of $1,632<10 \mathrm{~d}$ ith so this does not happen regression model multikolinearitas.

\section{Autocorrelation Test}

Autocorrelation testing is used to determine whether there is any correlation between the sample members. Testing is done with the Darbin-Watson test (DW test). The test results are presented in table 3.

Table 3

Autocorrelation Test Results

Model Summary ${ }^{b}$

\begin{tabular}{ll|r|r|r|r}
\hline Model & $\mathrm{R}$ & R Square & Adjusted R Square & $\begin{array}{c}\text { Std. Error of the } \\
\text { Estimate }\end{array}$ & Durbin-Watson \\
\hline 1 & $.725^{\mathrm{a}}$ & 526 & .516 & 2,535 & 2,038 \\
\hline
\end{tabular}

a. Predictors: (Constant), Career Development (X2), Placement (X1)

b. Dependent Variable: Employee Performance (Y)

The results of the test in table 3 obtained the Durbin-Watson value of 2.038 this value is between the interval of $1,550-2,460$. Thus the regression model stated no autocorrelation disorders. 
Ade Muslimat; The Effect of Placement and Career Development on Employee Performance ...| 187

\section{Heteroscasticity test}

Heteroscedasticity testing is intended to test whether in a regression model residual variance inequality occurs .

Table 4

Heteroskesdasticity Test Results with the Glejser Test Model

Coefficients $^{\text {a }}$

\begin{tabular}{|c|c|c|c|c|c|c|}
\hline \multirow{2}{*}{\multicolumn{2}{|c|}{ Model }} & \multicolumn{2}{|c|}{$\begin{array}{l}\text { Unstandardized } \\
\text { Coefficients }\end{array}$} & \multirow{2}{*}{$\begin{array}{c}\text { Standardized } \\
\text { Coefficients } \\
\text { Beta } \\
\end{array}$} & \multirow[b]{2}{*}{$\mathrm{t}$} & \multirow[b]{2}{*}{ Sig. } \\
\hline & & $\mathrm{B}$ & Std. Error & & & \\
\hline \multirow[t]{3}{*}{1} & (Constant) & 1,732 & 1,759 & & .985 & .327 \\
\hline & Placement (X1) &,- 040 & .051 & -.105 & -772 & .430 \\
\hline & Career Development (X2) & .477 & .054 & 115 & .870 & 387 \\
\hline
\end{tabular}

a. Dependent Variable: RES2

Testing by using test glejser was obtained value Sig. $>0.05$. Therefore, the regression model does not have heteroscasticity disorder.

\section{Descriptive Analysis}

This test is used to determine the minimum and maximum scores, mean scores and standard deviations of each variable. The results are presented in table 5.

\section{Table 5}

\section{Descriptive Statistics Analysis Results}

\begin{tabular}{l|r|r|r|r|r}
\hline & N & Minimum & Maximum & $\begin{array}{c}\text { The } \\
\text { mean }\end{array}$ & Std. Deviation \\
\hline Placement (X1) & 95 & 32 & 48 & 38.43 & 3,937 \\
\hline Career Development (X2) & 95 & 30 & 45 & 38.48 & 3,695 \\
\hline Employee Performance (Y) & 95 & 32 & 46 & 39.21 & 3,643 \\
\hline Valid N (listwise) & 95 & & & & \\
\hline
\end{tabular}

Placement obtained a minimum variance of 32 and a maximum variance of 48 with a mean score of 3.84 with a standard deviation of 3.937. Career development obtained a minimum variance of 30 and a maximum variance of 45 with a mean score of 3.84 with a standard deviation of 3.695. Employee performance obtained a minimum variance of 32 and a maximum variance of 46 with a mean score of 3.92 with a standard deviation of 3.643 . 
188 Jurnal Ilmiah Ilmu Administrasi Publik: Jurnal Pemikiran dan Penelitian Administrasi Publik Volume 10 Number 1, January - June 2020. Page 183-194

\section{Verification Analysis}

This analysis is intended to determine the effect of independent variables on the dependent variable. The test results are as follows:

\section{Multiple Linear Regression Analysis}

This regression test is intended to determine changes in the dependent variable if the independent variable changes. The test results are as follows:

Table 6 .

\section{Multiple Linear Regression Testing Results}

\begin{tabular}{|c|c|c|c|c|c|}
\hline \multirow[b]{3}{*}{ Model } & \multicolumn{5}{|c|}{ Coefficients a } \\
\hline & \multicolumn{2}{|c|}{$\begin{array}{c}\text { Unstandardized } \\
\text { Coefficients }\end{array}$} & \multirow{2}{*}{$\begin{array}{c}\text { Standardized } \\
\text { Coefficients } \\
\text { Beta }\end{array}$} & \multirow[b]{2}{*}{$\mathrm{t}$} & \multirow[b]{2}{*}{ Sig. } \\
\hline & $\mathrm{B}$ & Std. Error & & & \\
\hline $1 \quad$ (Constant) & 9,565 & 2,946 & & 3,246 & .002 \\
\hline Placement (X1) & .352 & .085 & .380 & 4,148 & .000 \\
\hline Career Development (X2) & .419 & .090 & .425 & 4,636 & .000 \\
\hline
\end{tabular}

a. Dependent Variable: Employee Performance (Y)

Based on the test results in the above table, the regression equation $\mathrm{Y}=9.565+0.352 \mathrm{X} 1$ $+0.419 \mathrm{X} 2$ is obtained. From the equation explained as follows:

1) A constant of 9.565 means that if there is no career placement and development, then there is an employee performance value of 9.565 points.

2) Placement regression coefficient of 0.352 , this number is positive meaning that every time there is an increase in placement of 0.352 , the employee's performance will also increase by 0.352 points.

3) The coefficient of career development regression is 0.419 , this number is positive meaning that every time there is an increase in career development by 0.419 , the employee's performance will also increase by 0.419 points.

\section{Correlation Coefficient Analysis}

Correlation coefficient analysis is intended to determine the level of strength of the relationship of the independent variable on the dependent variable both partially and simultaneously. The test results are presented in table 7 . 
Ade Muslimat; The Effect of Placement and Career Development on Employee Performance ... 189

Table 7

Placement Correlation Coefficient Testing Results on Employee Performance.

Correlations $^{b}$

\begin{tabular}{llr|rr}
\hline & & & \multicolumn{2}{c}{$\begin{array}{r}\text { Employee Performance } \\
\text { (Y) }\end{array}$} \\
\hline Placement (X1) & Pearson Correlation & 1 & $.645^{* *}$ \\
\cline { 2 - 4 } & Sig. (2-tailed) & & .000 \\
\hline $\begin{array}{l}\text { Employee Performance } \\
\text { (Y) }\end{array}$ & Pearson Correlation & $.645^{* *}$ & 1 \\
\cline { 2 - 5 } & Sig. (2-tailed) & .000 & \\
\hline
\end{tabular}

**. Correlation is significant at the 0.01 level (2-tailed).

b. Listwise $\mathrm{N}=95$

Based on the test results obtained a correlation value of 0.645 means that placement has a strong relationship with employee performance.

Table 8

Career Development Correlation Coefficient Test Results on Employee Performance.

Correlations $^{b}$

\begin{tabular}{llrr|r}
\hline & & $\begin{array}{c}\text { Career Development } \\
(\mathrm{X} 2)\end{array}$ & \multicolumn{2}{c}{$\begin{array}{c}\text { Employee } \\
\text { Performance } \\
(\mathrm{Y})\end{array}$} \\
\hline Career Development (X2) & Pearson Correlation & 1 & $.662^{\text {** }}$ \\
\cline { 2 - 4 } & Sig. (2-tailed) & .000 \\
\hline Employee Performance (Y) & Pearson Correlation & $.662^{\text {** }}$ & 1 \\
\cline { 2 - 5 } & Sig. (2-tailed) & .000 & \\
\hline
\end{tabular}

**. Correlation is significant at the 0.01 level (2-tailed).

b. Listwise $\mathrm{N}=95$

Based on the test results obtained a correlation value of 0.662 means that career development has a strong relationship to employee performance.

Table 9

Simultaneous Correlation Test Results Placement and career development simultaneously on employee performance.

Summary Model

\begin{tabular}{lr|r|r|r}
\hline Model & R & R Square & Adjusted R Square & Std. Error of the Estimate \\
\hline 1 & $.725^{\mathrm{a}}$ & 526 & .516 & 2,535 \\
\hline
\end{tabular}

a. Predictors: (Constant), Career Development (X2), Placement (X1)

Based on the test results obtained a correlation value of 0.725 means that simultaneous career placement and development have a strong relationship to employee performance. 
190 | Jurnal Ilmiah Ilmu Administrasi Publik: Jurnal Pemikiran dan Penelitian Administrasi Publik Volume 1o Number 1, January - June 2020. Page 183-194

\section{Analysis of the Coefficient of Determination}

Analysis of the coefficient of determination is intended to determine the percentage of influence of the independent variable on the dependent variable either partially or simultaneously. The test results can be seen in tables 10, 11, 12 .

Table 10

Test Results for Placement Determination Coefficient on Employee Performance.

Summary Model

\begin{tabular}{|c|c|c|c|c|}
\hline Model & $\mathrm{R}$ & R Square & Adjusted R Square & Std. Error of the Estimate \\
\hline 1 & $.645^{\mathrm{a}}$ & .416 & .409 & 2,800 \\
\hline
\end{tabular}

a. Predictors: (Constant), Placement (X1)

Based on the test results obtained a determination value of 0.416 means that placement has an influence contribution of $41.6 \%$ on employee performance.

Table 11

Career Development Determination Coefficient Test Results on Employee Performance. Summary Model

\begin{tabular}{lr|r|r|r}
\hline Model & R & R Square & Adjusted R Square & Std. Error of the Estimate \\
\hline 1 & $.662^{\mathrm{a}}$ & .438 & .432 & 2,747 \\
\hline
\end{tabular}

a. Predictors: (Constant), Career Development (X2)

Based on the test results obtained a determination value of 0.438 means that career development has an influence contribution of $43.8 \%$ on employee performance.

Table 12

Test Results for Placement Determination Coefficient and Career Development on Employee Performance

Summary Model

\begin{tabular}{lr|r|r|r}
\hline Model & R & R Square & Adjusted R Square & Std. Error of the Estimate \\
\hline 1 & $.725^{\text {a }}$ & 526 & .516 & 2,535 \\
\hline
\end{tabular}

a. Predictors: (Constant), Career Development (X2), Placement (X1)

Based on the test results obtained a determination value of 0.526 means that placement and career development simultaneously has an influence contribution of $52.6 \%$ on employee performance, while the remaining $47.4 \%$ is influenced by other factors. 


\section{Hypothesis testing}

\section{Partial hypothesis test ( $t$ test)}

Hypothesis testing with $\mathrm{t}$ test is used to find out which partial hypotheses are accepted. First Hypothesis: There is a significant influence between placement on employee performance.

Table 13

Placement Hypothesis Test Results on Employee Performance.

Coefficients ${ }^{\text {a }}$

\begin{tabular}{|c|c|c|c|c|c|}
\hline \multirow[b]{2}{*}{ Model } & \multicolumn{2}{|c|}{ Unstandardized Coefficients } & \multirow{2}{*}{$\begin{array}{c}\text { Standardized Coefficients } \\
\text { Beta }\end{array}$} & \multirow[t]{2}{*}{$t$} & \multirow{2}{*}{ Sig. } \\
\hline & B & Std. Error & & & \\
\hline (Constant) & 16,284 & 2,834 & & 5,4747 & .000 \\
\hline Placement (X1) & 597 & .73 & .645 & 8,133 & .000 \\
\hline
\end{tabular}

a. Dependent Variable: Employee Performance (Y)

Based on the test results in the above table, the value of $t_{\text {count }}>t_{\text {table }}$ or $(8.133>1.986)$ is obtained, thus the first hypothesis proposed that there is a significant influence on the placement of employees is accepted.

Table 14

Career Development Hypothesis Test Results on Employee Performance.

Coefficients ${ }^{\text {a }}$

\begin{tabular}{|c|c|c|c|c|c|}
\hline & \multicolumn{2}{|c|}{ Unstandardized Coefficients } & Standardized Coefficients & t & Sig. \\
\hline Model & B & Std. Error & Beta & & \\
\hline (Constant) & 14.109 & 2,964 & & 4,761 & .000 \\
\hline $\begin{array}{l}\text { Career } \\
\text { Development } \\
\text { (X2) }\end{array}$ & 652 & .077 & .662 & 8,508 & .000 \\
\hline
\end{tabular}

a. Dependent Variable: Employee Performance (Y)

Based on the test results in the table above, obtained the value of $t_{\text {count }}>t_{\text {table }}$ or (8.508> 1.986), thus the second hypothesis proposed that there is a significant influence between career development on employee performance is accepted.

\section{Simultaneous Hypothesis Test (Test F)}

Hypothesis testing with the F test is used to find out which simultaneous hypotheses are accepted. The third hypothesis There is a significant influence between career placement and development on employee performance. 
192 Jurnal Ilmiah Ilmu Administrasi Publik: Jurnal Pemikiran dan Penelitian Administrasi Publik Volume 1o Number 1, January - June 2020. Page 183-194

Table 15

Career Placement Hypothesis Test Results on Employee Performance.

\begin{tabular}{lr|r|r|r|r}
\multicolumn{7}{c}{ ANOVA $^{\text {a }}$} \\
\hline Model & Sum of Squares & \multicolumn{1}{c}{ df } & Mean Square & F & Sig. \\
\hline Regression & 656,700 & 2 & 328,350 & 51,106 & $.000^{\mathrm{b}}$ \\
\hline Residual & 591,090 & 92 & 6,425 & & \\
\hline Total & 1247,789 & 94 & & & \\
\hline
\end{tabular}

a. Dependent Variable: Employee Turn Over Intention (Y)

b. Predictors: (Constant), Job Satisfaction (X2), Job Placement (X1)

Based on the test results in the above table, the calculated $F_{\text {value }}>F_{\text {table }}$ or $(51.106>2,700)$, thus the third hypothesis proposed that there is a significant influence between placement and career development on employee performance is accepted.

\section{Discussion}

\section{Effect of Placement on Employee Performance}

The results of the analysis showed that the placement variable had a significant effect on employee performance with a correlation value of 0.645 , meaning that the two variables had a strong relationship with a contribution of $41.6 \%$. Hypothesis testing obtained values of $t_{\text {count }}>t$ table or $(8,133>1,986)$. Thus the first hypothesis proposed that there is a significant effect between placement on employee performance is accepted.

\section{Effect of career development on employee performance}

The results of the analysis obtained career development variables significantly influence employee performance with a correlation value of 0.662 meaning that both variables have a strong relationship with a contribution of $43.8 \%$. Hypothesis testing obtained $t$ value $>t$ table or (8.508> 1.986). Thus the second hypothesis proposed that there is a significant effect between career development on employee performance is accepted.

\section{Effect of Placement and Career Development on Employee Performance}

the results of the analysis obtained the placement and career development variables significantly influence employee performance by obtaining a regression equation $\mathrm{Y}=9.565+$ $0.352 \mathrm{X} 1+0.419 \mathrm{X} 2$, the correlation value of 0.725 means that both variables have a strong relationship with the contribution of influence of $52.6 \%$ while the remaining $47,4 \%$ influenced by other factors. Hypothesis testing obtained by calculating the $F_{\text {value }}>F_{\text {table }}$ or $(51.106>2,700)$. Thus the third hypothesis proposed that there is a significant effect between placement and career development on employee performance is accepted. 


\section{CONCLUSION}

Placement has a significant effect on employee performance with a correlation value of 0.645 or strong with an influence contribution of $41.6 \%$. Hypothesis testing obtained $t_{\text {count }}>t_{\text {table }}$ or $(8,133>1,986)$. Thus there is a significant effect between placement on employee performance at PT. Mandiri Karya in Jakarta. Career development has a significant effect on employee performance with a correlation value of 0.662 or strong with a contribution of $43.8 \%$. Hypothesis testing obtained $t_{\text {count }}>t_{\text {table }}$ or $(8.508>1.986)$. Thus there is a significant influence between career development on employee performance at PT. Mandiri Karya in Jakarta. Career placement and development have a significant effect on employee performance with a correlation value of 0.725 or strong with a contribution of $52.6 \%$ while the remaining $47.4 \%$ is influenced by other factors. Hypothesis testing obtained by the calculated $F_{\text {value }}>\mathrm{F}$ table or (51.106> 2.700). Thus there is a significant effect between career placement and career development simultaneously on employee performance at PT. Mandiri Karya in Jakarta.

\section{REFERENCES}

Asmanurhidayani, A., Saggaf, M. S., \& Salam, R. (2018). The Effect Of Cooperation On Quality Work At Family Planning Office And Family Welfare Office In Wajo Regency.

Bott, J.-B., Muller, M.-A., Jackson, J., Aubert, J., Cassel, J.-C., Mathis, C., \& Goutagny, R. (2016). Spatial reference memory is associated with modulation of theta-gamma coupling in the dentate gyrus. Cerebral Cortex, 26(9), 3744-3753.

Creswell, J. W. (2013). Research Design: Qualitative Approach, Quantitative and Mixed. Yogyakarta: Student Library.

Creswell, J. W., \& Creswell, J. D. (2017). Research design: Qualitative, quantitative, and mixed methods approaches. Sage publications.

Creswell, J. W., \& Poth, C. N. (2018). Qualitative inquiry Research Design Choosing Among Five Approaches (Vol. 53, Issue 9). SAGE Publications Ltd. https://doi.org/10.1017/CBO9781107415324.004

Daraba, D., Subianto, A. B., \& Salam, R. (2018). An effort to Improve the Quality of Workers at the Makassar city Department of Employment Services. Jurnal Ilmiah Ilmu Administrasi Publik, 8(1), 21-26.

Eka, P. D. (2020). The Effect of Leadership and Motivation on Organizational Commitment at PT. Indo Perkasa Indonesia in Tangerang. PINISI Discretion Review, 1(2), 73-80.

Hanrahmawan, F. (2012). Revitalisasi Manajemen Pelatihan Tenaga Kerja (Studi Kasus Pada Balai Latihan Kerja Industri Makassar). Jurnal Ilmiah Ilmu Administrasi Publik, 1(1), 7894.

Hermawati, R., \& Fadillah, A. T. (2018). The Effect of Motivation and Work Discipline on the Employee Performance at PT. Tunas Rental Thamrin Jakarta. PINISI Discretion Review, $2(1), 43-52$. 
194 | Jurnal Ilmiah Ilmu Administrasi Publik: Jurnal Pemikiran dan Penelitian Administrasi Publik Volume 10 Number 1, January - June 2020. Page 183-194

Jasmani, J. (2019). The Effect of Liquidity and Working Capital Turnover on Profitability at PT. Sumber Cipta Multiniaga, South Jakarta. PINISI Discretion Review, 3(1), 29-38.

Juhaeri, J. (2020). The Influence of Brand Image, Service Quality, Price Perception and Trust on the Purchase Decision of Welding Workshop Welding Www. Kanopirumah. Com. PINISI Discretion Review, 2(1), 17-24.

Kampkötter, P. (2017). Performance appraisals and job satisfaction. The International Journal of Human Resource Management, 28(5), 750-774.

Ogar, J. N., \& Ude, N. C. (2020). Organizational Dynamics and Public Service Ethics in Nigeria. PINISI Discretion Review, 1(1), 217-224.

Pratiwi, N. J., Jamaluddin, J., Niswaty, R., \& Salam, R. (2019). The Influence of Work Facilities on Employee Performance at the Regional Financial Management Agency Secretariat Section of South Sulawesi Province. Jurnal Ad'ministrare, 6(1), 35-44.

Scott, T. W., \& Tiessen, P. (1999). Performance measurement and managerial teams. Accounting, Organizations and Society, 24(3), 263-285.

Yildiz, B., Bilbao, J. I., \& Sproul, A. B. (2017). A review and analysis of regression and machine learning models on commercial building electricity load forecasting. Renewable and Sustainable Energy Reviews, 73, 1104-1122. 